\title{
PENERAPAN UNIVERSAL PRECAUTION UNTUK PENCEGAHAN PENULARAN HIV-AIDS
}

\author{
Lusi Andriani \\ Politeknik Kesehatan Kementerian Kesehatan Bengkulu, Jurusan Kebidanan, \\ Jalan Indragiri Nomor 3 Padang Harapan Kota Bengkulu \\ andrianilusi@ymail.com
}

\begin{abstract}
Universal Precaution socialization for midwives in Bengkulu had been realized since 2000 by giving preventive on infection (PI) information, but in fact UP implementation does not implemented properly so the risk of HIV \& AIDS transmission becoming higher. The purpose of this research for analyze Universal Precaution practice by the midwives in delivery service for prevent HIV \& AIDS transmission. This research is a part of explanatory research with cross sectional approaching. The sample of this research is the number of total population who included in the inclusion criteria, they are 220 midwives. The data collection was using questionnaire and for crosscheck data was using indepth interview on 6 key informants. analyzing data using descriptive analysis and content analysis. There are five variables were giving the influences on this research, they are : the knowledge about HIV with $\mathrm{OR}=16.990$, the knowledge on Universal Precaution with $\mathrm{OR}=3.214$, attitudes on HIV with $\mathrm{OR}=9.719$, resources with $\mathrm{OR}=28.416$ and policy with $\mathrm{OR}=4.847$.
\end{abstract}

Keywords : UP Implementation, Woman delivery Service

\begin{abstract}
Abstrak : Sosialisasi mengenai Universal Precaution (UP) pada bidan di kota Bengkulu telah dilakukan sejak tahun 2000 melalui pemberian informasi Pencegahan Infeksi (PI), namun pada kenyataannya praktik UP tidak dilaksanakan secara baik dan benar, sehingga resiko penularan HIV \& AIDS semakin besar. Tujuan dari penelitian ini adalah mengetahui penerapan UP oleh bidan dalam pertolongan persalinan untuk pencegahan penularan HIV \& AIDS. Penelitian ini menggunakan metode explanatory research dengan pendekatan potong silang. Sampel adalah total populasi yang masuk dalam kriteria inklusi yaitu 220 orang bidan, pengumpulan data menggunakan kuesioner dan untuk data Crosscheck dilakukan melalui indepth interview terhadap 6 orang informan. Data dianalisa secara deskriptif dan analisis isi. Terdapat 5 variabel yang berpengaruh yaitu : pengetahuan tentang HIV OR= 16.990, pengetahuan terhadap UP OR=3.214, sikap terhadap $\mathrm{HIV} O \mathrm{OR}=9.719$, sarana prasarana $\mathrm{OR}=28.416$ dan kebijakan $\mathrm{OR}=4.847$.
\end{abstract}

Kata kunci : Determinan, Penerapan UP, Pertolongan Persalinan

Virus HIV dan Hepatitis memiliki peluang untuk menular di sarana pelayanan kesehatan, baik dari pasien ke petugas kesehatan, maupun dari pasien ke pasien bahkan, dari petugas kesehatan ke pasien. Menurut Schilo dkk (1993) dari penelitian di Michigan Amerika Serikat menunjukkan masih banyak paramedis yang tidak konsisten dalam penerapan universal precaution (UP). Risiko penularan penyakit yang dapat ditularkan melalui darah sangat berpengaruh dari perilaku para petugas kesehatan (Mayfield, 1993).

World Health Organization (WHO) mensinyalir dari 35 juta petugas kesehatan di seluruh dunia, diperkirakan sekitar 3 juta mengalami pajanan patogen darah setiap tahun, 2 juta terpajan virus Hepatitis B, 0,9 juta terpajan hepatitis $C, 17$ ribu kasus heaptitis B dan 100 kasus HIV \& AIDS, lebih dari $90 \%$ (15.300 kasus) penyakit infeksi terdapat di negara yang sedang berkembang (Depkes RI,2003 dan Wu Sheng, 2008)

Sejak tahun 2002 penularan infeksi HIV juga telah meluas ke rumah tangga. Di Jakarta dilaporkan bahwa sekitar 3\% dari $500 \mathrm{ibu}$ hamil yang dites secara sukarela dalam kegiatan Voluntary Counseling Testing (VCT) sudah terinfeksi HIV. Bahkan sejak pertengahan tahun 1996 juga dilaporkan HIV merenggut kelompok ibu-ibu rumah tangga 
dan bayi yang lahir dari ibu HIV positif (Kemenkes, 2011).

Prevalensi infeksi HIV \& AIDS di propinsi Bengkulu setiap tahun jumlahnya meningkat. Jika dilihat dari data 2003 hingga 2011 terjadi peningkatan yang cukup tajam. Dilaporkan sejumlah 296 orang yang terinfeksi HIV pada tahun 2010 terdiri dari 197 orang pria, 98 orang wanita dan 1 waria. Dari 98 orang wanita yang dilaporkan HIV positif tersebut terdapat 2 orang ibu bersalin dengan anak yang juga tertular HIV positif. Sedangkan tahun 2011 dari 400 orang yang terinfeksi terdiri dari 200 orang wanita, 187 pria dan 13 waria (Dinkes Propinsi Bengkulu, 2010)

Bidan sebagai salah satu pemberi layanan kesehatan lini terdepan yang dalam tugasnya dapat berisiko terhadap tertular penyakit dari pasien yang ditolongnya seperti penyakit HIV \& AIDS dan Hepatitis (Depkes RI, 2003 dan Nursalam, 2009). Dengan meningkatnya kasus HIV \& AIDS pada ibu rumah tangga, maka bidan merupakan populasi yang memiliki risiko tinggi untuk dapat tertular, karena sebagian besar pasien bidan adalah ibu rumah tangga yang sebagian besar memeriksakan kesehatan terutama dalam pertolongan persalinannya ditolong oleh bidan (Tietjen, Linda, 2004)

Sosialisasi mengenai UP pada bidan di kota Bengkulu telah dilakukan sejak tahun 2000 melalui pemberian informasi PI yang termasuk dalam materi pelatihan APN, namun pada kenyataannya praktik UP tidak dilaksanakan secara baik dan benar sehingga resiko penularan HIV \& AIDS semakin besar. Fakta lain sebaran kasus penyakit ini kurang diinformasikan kepada seluruh petugas kesehatan termasuk bidan.

Bidan di Kota Bengkulu berjumlah 248 orang sedangkan yang sudah mendapat pelatihan APN sebanyak 200 orang, jumlah persalinan tahun 2010 adalah 5076 persalinan, yang ditolong oleh tenaga kesehatan sebanyak $4512(88,9 \%)$. Dilaporkan dari jumlah persalinan yang ditolong oleh tenaga kesehatan 2700 persalinan $(53,19 \%)$ ditolong oleh bidan (Dinkes Propinsi Bengkulu, 2010). Permasalahan yang dihadapi adalah adalah faktor apa yang mempengaruhi bidan dalam penerapan UP pada pertolongan persalinan sebagai upaya pencegahan penularan HIV \& AIDS di Kota Bengkulu.

\section{BAHAN DAN CARA KERJA}

Jenis penelitian ini merupakan Explanatory Research. dengan pendekatan crosssectional dikombinasikan dengan crosscheck data triangulasi. Populasi penelitian ini adalah semua bidan yang berada di Kota Bengkulu berjumlah 220 orang yang memenuhi kriteria inklusi sudah melakukan pertolongan persalinan minimal 1 tahun dan berdomisili di Kota Bengkulu. Crosscheck dilakukan dengan cara triangulasi sumber yang dilakukan pada subyek penelitian masingmasing 2 orang yaitu pihak Dinas Kesehatan, Pengurus IBI Kota Bengkulu dan Atasan tempat bidan bekerja (2 orang). Varaiabel yang diteliti adalah usia, pendidikan, masa kerja, pengetahuan tentang HIV, pengetahuan tentang UP, sikap terhadap HIV, sikap terhadap UP, kebijakan, dukungan teman, dukungan IBI, dukungan dinas kesehatan dan kepatuhan pelaksanaan UP. Data dianalisis secara univariat, bivariat dengan uji chisquare dan multivariat dengan regresi logistik.

HASIL

\section{Analisis Univariat}

Tabel 1. Distribusi Frekuensi Umur, Pendidikan, Masa Kerja Bidan

\begin{tabular}{lcc}
\hline \multicolumn{1}{c}{ Variabel } & F & \% \\
\hline Umur & & \\
$<30$ tahun & 178 & 19.1 \\
$\geq 30$ tahun & 42 & 80.9 \\
Pendidikan & & \\
D I & 51 & 23.2 \\
$\geq$ D III/DIV/S1/S2 & 169 & 76.8 \\
Masa Kerja & & \\
$<5$ tahun & 57 & 25.1 \\
$\geq 5$ tahun & 163 & 74.1 \\
\hline
\end{tabular}

Berdasarkan Tabel 1 dari 220 orang responden hampir seluruhnya berada pada ke- 
lompok umur $\geq 30$ tahun ( $80.9 \%$ ), dilihat dari pendidikan hampir seluruhnya mempunyai pendidikan $\geq$ DIII/DIV/S1/S2 (76.8\%) dan sebagian besar dengan masa kerja $\geq 5$ tahun $(74.1 \%)$.

Tabel 2. Distribusi Frekuensi Pengetahuan HIV dan UP, Sikap Terhadap HIV dan UP, Kebijakan, Dukungan Teman, IBI, DinKes dan Kepatuhan Pelaksanaan UP

\begin{tabular}{|c|c|c|}
\hline Variabel & $\mathbf{F}$ & $\%$ \\
\hline \multicolumn{3}{|l|}{ Pengetahuan HIV } \\
\hline Baik & 111 & 50.5 \\
\hline Kurang Baik & 109 & 49.5 \\
\hline \multicolumn{3}{|l|}{ Pengetahuan UP } \\
\hline Baik & 112 & 50.9 \\
\hline Kurang Baik & 108 & 49.1 \\
\hline \multicolumn{3}{|c|}{ Sikap Terhadap HIV } \\
\hline Baik & 106 & 48.2 \\
\hline Kurang Baik & 114 & 51.8 \\
\hline \multicolumn{3}{|c|}{ Sikap Terhadap UP } \\
\hline Tersedia & 148 & 67.3 \\
\hline Tidak Tersedia & 72 & 32.7 \\
\hline \multicolumn{3}{|l|}{ Kebijakan } \\
\hline Ada & 143 & 65.0 \\
\hline Tidak Ada & 77 & 35.0 \\
\hline \multicolumn{3}{|l|}{ Dukungan Teman } \\
\hline Ada & 191 & 86.8 \\
\hline Tidak Ada & 29 & 13.2 \\
\hline \multicolumn{3}{|l|}{ Dukungan IBI } \\
\hline Ada & 141 & 64.1 \\
\hline Tidak ada & 79 & 35.9 \\
\hline \multicolumn{3}{|l|}{ Dukungan DinKes } \\
\hline Ada & 106 & 48.2 \\
\hline Tidak Ada & 114 & 51.8 \\
\hline \multicolumn{3}{|l|}{$\begin{array}{l}\text { Kepatuhan } \\
\text { Pelaksanaan UP }\end{array}$} \\
\hline Patuh & 84 & 38.2 \\
\hline Tidak Patuh & 136 & 61.8 \\
\hline
\end{tabular}

Berdasarkan Tabel 2 Variabel pengetahuan bidan tentang HIV dan pengetahuan tentang UP hampir sama yaitu setengah dari responden mempunyai pengetahuan baik
(50.5\%) tentang pengetahuan HIV dan $(50.9 \%)$ pengetahuan tentang UP, sedangkan sikap terhadap UP sebagian besar responden $(61.8 \%)$ mempunyai sikap baik lebih banyak dibandingkan sikap terhadap HIV yaitu hanya (48.2\%) yang bersikap baik.

Sebagian besar responden $(51.8 \%)$ telah mempunyai sarana dan prasarana lengkap dan sebagian besar $(67.3 \%)$ tersedia standar pelayanan. Sebagian besar bidan $(65 \%)$ mengatakan ada kebijakan, hampir seluruh bidan mengatakan ada dukungan dari teman $(86.8 \%)$, hanya $(35.9 \%)$ yang mengatakan tidak ada dukungan dari IBI dan hanya (48.2\%) ada dukungan dari dinas kesehatan. Hasil penelitian menunjukkan sebagian besar bidan $(61.8 \%)$ tidak patuh dalam pelaksanaan UP dalam pertolongan persalinan di Kota Bengkulu tahun 2012.

\section{Analisis Bivariat}

Berdasarkan tabel 2 diketahui dari 220 orang bidan yang mempunyai pengetahuan baik tentang HIV lebih banyak yang patuh (65.8\%) dibandingkan dengan pengetahuan kurang baik $(10.1 \%)(\rho=0.000)$, demikian juga dengan bidan yang mempunyai pengetahuan baik tentang UP lebih banyak yang patuh dalam pelaksanaan UP (59.8\%) dibandingkan dengan yang pengetahuannya kurang baik $(15.7 \%)(\rho=0.000)$.

Sikap terhadap HIV dan sikap terhadap UP juga menunjukkan bahwa bidan yang mempunyai sikap baik cenderung patuh dalam pelaksanaan UP $(\rho=0.000)$. Hasil analisis menunjukkan bidan dengan sarana lengkap lebih banyak yang patuh dalam pelaksanaan UP (65.8\%) dibandingkan bidan yang sarana dan prasarana tidak lengkap $(8.5 \%)(\rho=0.000)$, demikian juga dengan bidan yang menyatakan ada kebijakan lebih banyak yang patuh $(51.7 \%)$ dibandingkan bidan yang menyatakan tidak ada kebijakan $(\rho=0.000)$. Sedangkan untuk variabel standar pelayanan, dukungan teman, dukungan IBI dan dukungan dinas kesehatan dari hasil analisis tidak didapatkan hubungan. 
Tabel 3. Hasil Analisis Hubungan Variabel Bebas dengan Pelaksanaan UP dalam Pertolongan Persalinan oleh Bidan

\begin{tabular}{|c|c|c|c|c|c|}
\hline \multirow{3}{*}{ Variabel } & \multicolumn{4}{|c|}{ Penerapan UP } & \multirow{3}{*}{$\rho$} \\
\hline & \multicolumn{2}{|c|}{ Patuh } & \multicolumn{2}{|c|}{ Tidak Patuh } & \\
\hline & $\mathbf{F}$ & $\%$ & $\mathbf{F}$ & $\%$ & \\
\hline $\begin{array}{l}\text { Pengetahu- } \\
\text { an HIV } \\
\text { Baik }\end{array}$ & 73 & 65.8 & 38 & 34.2 & 0.000 \\
\hline Kurang Baik & 11 & 10.1 & 98 & 89.9 & \\
\hline $\begin{array}{l}\text { Pengetahu- } \\
\text { an UP }\end{array}$ & & & & & \\
\hline Baik & 67 & 59.8 & 45 & 40.2 & 0.000 \\
\hline Kurang Baik & 17 & 15.7 & 91 & 84.3 & \\
\hline $\begin{array}{l}\text { Sikap } \\
\text { Terhadap } \\
\text { HIV } \\
\text { Baik }\end{array}$ & 65 & 61.3 & 41 & 38.7 & 0000 \\
\hline Kurang Baik & 19 & 16.7 & 95 & 83.3 & \\
\hline $\begin{array}{l}\text { Sikap } \\
\text { Terhadap } \\
\text { UP }\end{array}$ & & & & & \\
\hline Baik & 61 & 44.9 & 75 & 55.1 & 0.010 \\
\hline Kurang Baik & 23 & 27.4 & 61 & 72.6 & \\
\hline $\begin{array}{l}\text { Sarana } \\
\text { Prasarana } \\
\text { Lengkap }\end{array}$ & 75 & 65.8 & 39 & 34.2 & 0.000 \\
\hline $\begin{array}{l}\text { Tidak } \\
\text { Lengkap } \\
\text { Standar } \\
\text { Pelayanan } \\
\text { Tersedia }\end{array}$ & 51 & 34.5 & 97 & 65.5 & 0.103 \\
\hline $\begin{array}{l}\text { Tidak } \\
\text { Tersedia } \\
\text { Kebijakan }\end{array}$ & 33 & 45.8 & 39 & 54.2 & \\
\hline Ada & 74 & 51.7 & 69 & 48.3 & 0.000 \\
\hline Tidak Ada & 10 & 13 & 67 & 87 & \\
\hline $\begin{array}{l}\text { Dukungan } \\
\text { Teman }\end{array}$ & & & & & \\
\hline Ada & 76 & 39.8 & 115 & 60.2 & 0.207 \\
\hline Tidak Ada & 8 & 27.6 & 21 & 72.4 & \\
\hline $\begin{array}{l}\text { Dukungan } \\
\text { IBI }\end{array}$ & & & & & \\
\hline Ada & 60 & 42.6 & 81 & 57.4 & 0.075 \\
\hline Tidak Ada & 24 & 30.4 & 55 & 69.6 & \\
\hline $\begin{array}{l}\text { Dukungan } \\
\text { Dinas }\end{array}$ & & & & & \\
\hline Ada & 54 & 50.9 & 52 & 49.1 & 0.000 \\
\hline Tidak Ada & 30 & 26.3 & 84 & 73.7 & \\
\hline
\end{tabular}

\section{Analisis Multivariat}

Tabel 4. Hasil Analisis Pengaruh Variabel Bebas terhadap Penerapan UP oleh Bidan Pada Pertolongan Persalinan Normal

\begin{tabular}{|c|c|c|c|c|c|c|}
\hline & B & S.E. & Wald & Sig. & $\begin{array}{l}\operatorname{Exp} \\
\text { (B) }\end{array}$ & $\begin{array}{r}95,0 \% \\
\text { C.I.for } \\
\text { EXP(B) }\end{array}$ \\
\hline $\begin{array}{l}\text { Pengeta- } \\
\text { huan } \\
\text { HIV }\end{array}$ & 2.833 & .733 & 14.934 & .000 & 16.990 & $\begin{array}{l}4.039- \\
71.471\end{array}$ \\
\hline $\begin{array}{l}\text { Pengeta- } \\
\text { huan UP }\end{array}$ & 1.167 & .514 & 5.167 & .023 & 3.214 & $\begin{array}{l}1.175- \\
8.793\end{array}$ \\
\hline $\begin{array}{l}\text { Sikap } \\
\text { terhadap } \\
\text { HIV }\end{array}$ & 2.274 & .544 & 17.470 & .000 & 9.719 & $\begin{array}{l}3.346- \\
28.233\end{array}$ \\
\hline Sarana & 3.347 & .677 & 24.455 & .000 & 28.416 & $\begin{array}{c}7.542- \\
107.071\end{array}$ \\
\hline $\begin{array}{l}\text { Kebijak- } \\
\text { an }\end{array}$ & 1.578 & .651 & 5.878 & .015 & 4.847 & $\begin{array}{l}1.353- \\
17.362\end{array}$ \\
\hline $\begin{array}{l}\text { Cons- } \\
\text { tant }\end{array}$ & -6.959 & 1.415 & 24.189 & .000 & .001 & \\
\hline
\end{tabular}

Hasil uji statistik multivariat pada tabel 4 diketahui bahwa terdapat 5 variabel yang memiliki nilai $\rho<0,05$, yaitu variabel pengetahuan tentang HIV ( $\rho=0,000, \mathrm{OR}=16.990$ ), variabel pengetahuan terhadap UP $(\rho=0,023$, $\mathrm{OR}=3.214)$, sikap terhadap HIV $(\rho=0,000$, $\mathrm{OR}=9.719)$, sarana prasarana $(\rho=0,000, \mathrm{OR}=$ 28.416) dan kebijakan $(\rho=0.015, \mathrm{OR}=4.847)$. Dari tabel tersebut diketahui nilai $\alpha$ adalah 6.956 dan nilai $\beta$ berturut-turut adalah sarana $(\beta=3.347)$, pengetahuan HIV $(\beta=2.833)$, sikap terhadap HIV $(\beta=2.274)$, kebijakan $(\beta=1.578)$ dan pengetahuan tentang UP $(\beta=$ 1.167) sedangkan nilai e adalah konstanta. Bila angka tersebut diatas dimasukkan kedalam persamaan regresi logistik maka diperoleh hasil sebesar 0.9853 (98.53\%), yang artinya apabila secara bersama-sama variabel sarana, pengetahuan tentang HIV, sikap terhadap HIV, kebijakan dan pengetahuan tentang UP dalam kategori baik, maka probabilitas untuk terjadinya kepatuhan dalam pelaksanaan UP dalam pertolongan persalinan adalah sebesar $98.53 \%$.

\section{PEMBAHASAN}

Penelitian ini berfokus pada penerapan UP pada pertolongan persalinan terutama 
dalam pencegahan dan penularan HIV/ AIDS, hasil penelitian menunjukkan sebagian besar responden $61.8 \%$ tidak patuh dalam penerapan UP dan sebanyak $38.2 \%$ yang patuh dalam penerapan UP pada pertolongan persalinan oleh bidan di kota Bengkulu.

Hasil wawancara dengan Ketua IBI dan wakil ketua 1 IBI Kota Bengkulu mengatakan dari hasil supervisi yang pernah dilakukan alat perlindungan diri yang seringkali tidak digunakan oleh bidan saat menolong persalinan adalah kacamata pelindung, masker dan sepatu boot. Ketua IBI juga menjelaskan bidan dalam hal dekontaminasi alat sering tidak menyikat alat setelah direndam dengan larutan klorin, jarang menggunakan sarung tangan rumah tangga pada saat mencuci alat, tidak melakukan dekontaminasi lantai dan tempat tidur dengan benar, tidak membuang sampah tajam pada tempat khusus karena tidak tersedia ditempat praktik.

Hasil analisis bivariat pada penelitian ini didapatkan variabel yang berhubungan dengan penerapan UP adalah variabel pengetahuan tentang HIV $(\mathrm{p}=0.000)$ dan pengetahuan UP $(\mathrm{p}=0.000)$, sikap terhadap HIV $(\mathrm{p}=$ 0.000) dan sikap terhadap UP $(\mathrm{p}=0.010)$, sarana dan prasarana $(\mathrm{p}=0.000)$, implementtasi kebijakan $(\mathrm{p}=0.000)$ dan dukungan dinas kesehatan $(\mathrm{p}=0.000)$.

Hasil uji statistik multivariat diperoleh 5 variabel yang berpengaruh yaitu pengetahuan tentang HIV nilai $\mathrm{OR}=16.990$, pengetahuan terhadap UP nilai $\mathrm{OR}=3.214$, sikap terhadap HIV nilai $\mathrm{OR}=9.719$, sarana prasarana nilai $\mathrm{OR}=28.416$, kebijakan dengan nilai $\mathrm{OR}=4.847$. Pengetahuan dan sikap bidan tentang HIV \& AIDS pada penelitian ini didapatkan pengaruhnya lebih kuat dibandingkan dengan sikap terhadap UP hal ini kemungkinan di sebabkan pengetahuan bidan yang masih kurang tentang HIV \& AIDS dan cara penularannya karena masih kurangnya sosialisasi yang diberikan, seperti informasi yang didapatkan dari hasil wawancara dengan pengurus IBI kota Bengkulu yang mengatakan bahwa sosialisasi tentang HIV \& AIDS tidak secara rutin diberikan hanya IBI pernah mengadakan seminar pada saat isu tentang HIV \& AIDS sedang berkembang dan setelah itu tidak pernah lagi diberikan.

Selain itu masih terdapat bidan yang menganggap bahwa resiko tertular HIV \& AIDS kemungkinan kecil karena sebagian besar pasien bidan adalah ibu-ibu rumah tangga dan anak-anak yang menurut bidan tidak beresiko untuk menularkan padahal jika bidan mengetahui bahwa siapapun bisa tertular HIV \& AIDS tidak melihat dari jenis aktivitas dan pekerjaannya. Oleh karena pengetahuan bidan yang kurang tentang HIV \& AIDS maka sikap bidan juga kurang mendukung dalam pencegahannya sehingga hal ini berdampak pada kepatuhan dalam pelaksanaan UP, bidan tidak melaksanakan UP secara benar karena bidan menganggap ia tidak beresiko tertular, hal ini didukung dengan tidak adanya monitoring dalam pelaksanaan UP baik dari organisasi profesi IBI maupun dari Dinas Kesehatan dimana dari pihak Dinas Kese-hatan didapatkan informasi dari hasil wawancara memang tidak pernah dilakukan monitoring dalam pelaksanaan UP pada bidan praktik swasta demikian juga dari organisasi profesi IBI hanya melakukan evaluasi setahun sekali.

Jika dilihat dari segi pendidikan ilmu pengetahuan tentang HIV \& AIDS tidak didapatkan bidan selama menempuh pendidikan dikarenakan pengetahuan tentang HIV \& AIDS belum masuk kedalam kurikulum pendidikan bidan yang seharusnya sejak masa pendidikan mahasiswa sudah diberikan pengetahuan tentang hal tersebut sehingga dapat menimbulkan sikap tidak menganggap remeh suatu penyakit terutama HIV \& AIDS yang berkembang sangat cepat dewasa ini.

Pada variabel sarana dan prasarana mempengaruhi penerapan UP karena secara umum merupakan alat penunjang keberhasilan apabila hal tersebut tidak tersedia maka semua kegiatan yang dilakukan tidak akan dapat mencapai hasil yang diharapkan (Lukman, 2000). Demikian juga seorang bidan dalam menjalankan tugasnya sesuai dengan PerMenKes RI nomor 572/ MenKes/VI/1996 harus dilengkapi dengan sarana prasarana yang menunjang sehingga bidan 
dalam bekerja mempunyai panduan yang harus dipedomani dan dilaksanakan (Pengurus IBI Pusat, 2007). Responden dalam penelitian ini yaitu bidan ditempat praktiknya hanya sebagian $(51.8 \%)$ yang memiliki sarana lengkap yang artinya masih banyak bidan yang belum melengkapi sarana dan prasarana terutama dalam pelaksanaan UP masih banyak bidan yang belum menyediakan masker, sepatu boot, kacamata, penutup kepala, sarung tangan rumah tangga, sarana dekontaminasi, sterilesasi dan pembuangan sampah medis tajam yang memadai. Bidan menganggap bahwa peralatan tersebut tidak perlu disediakan selain karena repot dalam menggunakan bidan menganggap resiko untuk tertular kecil, hal ini juga didukung dengan tidak adanya monitoring dan sanksi yang diberikan oleh organisasi profesi maupun IBI sehingga tidak ada yang mendukung dalam kepatuhan pelaksanaan UP. Demikian juga dengan adanya kebijak-an dimana kebijakan merupakan aturan yang bersifat tertulis dan mengikat yang akan menjadi rujukan bagi bidan dalam melaksa-nakan tugasnya sehingga timbul suatu kepa-tuhan dan apabila didukung oleh pihak yang berwenang dalam hal ini dinas kesehatan maka kepatuhan tersebut akan semakin baik.

\section{DAFTAR RUJUKAN}

Budianto Agung Analisis Pengaruh Pengetahuan dan Sikap Bidan Dalam Praktek Universal Precaution Pada Pertolongan Persalinan di Wilayah Eks Kawedanan Wanadadi Banjarnegara. Tesis. 2010

Brook G.F, Butel J.S, Morse S.A, Jawets, Melnick \& Adelberg. Medical Microbiology $23^{\text {th }}$ edition. McGra Hill. 2005.

Depkes RI. Panduan Pelaksanaan Kewaspadaan Universal. Jakarta. Depkes RI. 2003.

Depkes. Ditjen PPM \& PL. Statistik Kasus HIV AIDS di Indonesia dilapor s/d September 2011. Jakarta. 2011.

Ibu Rumah Tangga Peringkat Kedua Penderita HIV/AIDS. Suara Merdeka Edisi Rabu 24 September 2008.

Depkes RI. Standar Pelayanan Kebidanan. Jakarta. Depkes RI. 2000.

Depkes RI. Etika dan Kode Etik Kebidanan. Jakarta. 2002.

\section{KESIMPULAN}

Berdasarkan tujuan dan hasil penelitian disimpulkan bahwa ada hubungan antara pengetahuan bidan tentang HIV/AIDS, pengetahuan bidan tentang UP, Sikap bidan terhadap HIV/AIDS, sikap bidan terhadap UP, sarana dan prasarana, implementtasi kebijakan dan dukungan dinas Kesehatan dengan penerapan UP dalam pertolongan persalinan. Tidak ada hubungan antara umur, masa kerja, pendidikan, standar pelayanan, dukungan teman sejawat, dukungan IBI dengan penerapan UP oleh bidan dalam pertolongan persalinan. Variabel yang berpengaruh terhadap penerapan UP adalah pengetahuan tentang HIV, pengetahuan terhadap UP, sikap terhadap HIV, sarana prasarana, dan kebijakan.

Diharapkan IBI bekerjasama dengan dinas kesehatan atau instansi lain untuk mengadakan pelatihan tentang HIV/AIDS dan bekerjasama dengan pihak institusi pendidikan agar materi tentang HIV/AIDS dapat diberikan secara khusus dalam kurikulum pembelajaran, serta melakukan monitoring dan evaluasi dalam pelayanan pertolongan persalinan di tempat praktik bidan minimal 3 bulan sekali.

Dinas Kesehatan Propinsi Bengkulu. Profil Dinas Kesehatan Propinsi Bengkulu Tahun 2010. Bengkulu. 2010.

Dunn WN. Analisis Kebijakan. Jakarta. 1999

Green.L.W. Health Promotion Planning An Educational and Environmental Approach. Mayfield Publishing Company. 2000.

Komisi Penanggulangan AIDS Nasional. Rencana Aksi Nasional Penanggulangan HIV dan AIDS Tahun 2010-2014. 2010.

Mayfield E. Universal Precaution. FDA Consumer. April 1993;27:3

Muninjaya Gde AA. AIDS di Indonesia, Masalah, Kebijakan dan Penanggulangannya. Jakarta. EGC. 1999.

Mustika Sofyan, Nur Aini Madjid, Ruslidjah S. Bidan Menyongsong Masa Depan. Cetakan Ke VII. Jakarta. Pengurus Pusat IBI. Jakarta. 2006.

Notoatmodjo S. Promosi Kesehatan dan Ilmu Perilaku. Jakarta. Rineka Cipta. 2007. 
68 Jurnal Media Kesehatan, Volume 7 Nomor 1, Februari 2014, hlm 01- 99

Notoatmodjo S. Promosi Kesehatan Teori dan Aplikasi. Jakarta. Rineka Cipta. 2007.

Nursalam. Kurniawati Dian Ninuk. Asuhan Keperawatan Pada Pasien Terinfeksi HIV/AIDS. Jakarta: Salemba Medika; 2009.

Schillo Barbara A, Reischl Thomas. M. HIV-Related Knowledge and Precaution Among Michigan Nurses. American Journal Of Public Health. Oktober 1993;83 : 1438-1442
Sugiyono. Statistik Untuk Penelitian. Bandung. Alfabeta. 2006.

Tietjen.Linda.dkk. Panduan Pencegahan Infeksi Untuk Fasilitas Pelayanan Kesehatan dengan Sumber Daya Terbatas. Jakarta. Yayasan Bina Pustaka Sarwono Prawirohardjo. 2004. 